\title{
MK-7 and Its Effects on Bone Quality and Strength
}

\author{
Toshiro Sato ${ }^{1, *}$, Naoko Inaba ${ }^{1}$ and Takatoshi Yamashita ${ }^{2}$ \\ 1 R\&D division, J-OILMILLS, Inc., Yokohama 230-0053, Japan; naoko.inaba@j-oil.com \\ 2 Fine Chemical Division, J-OILMILLS, Inc., Tokyo 104-0044, Japan; takatoshi.yamashita@j-oil.com \\ * Correspondence: toshiro.sato@j-oil.com; Tel.: +81-45-503-2624
}

Received: 26 February 2020; Accepted: 28 March 2020; Published: 31 March 2020

\begin{abstract}
Vitamin $\mathrm{K}$ acts as a cofactor and is required for post-translational $\gamma$-carboxylation of vitamin K-dependent proteins (VKDP). The current recommended daily intake (RDI) of vitamin K in most countries has been established based on normal coagulation requirements. Vitamin $\mathrm{K} 1$ and menaquinone (MK)-4 has been shown to decrease osteocalcin (OC) $\gamma$-carboxylation at RDI levels. Among the several vitamin K homologs, only MK-7 (vitamin K2) can promote $\gamma$-carboxylation of extrahepatic VKDPs, OC, and the matrix Gla protein at a nutritional dose around RDI. MK-7 has higher efficacy due to its higher bioavailability and longer half-life than other vitamin $\mathrm{K}$ homologs. As vitamin K1, MK-4, and MK-7 have distinct bioactivities, their RDIs should be established based on their relative activities. MK-7 increases bone mineral density and promotes bone quality and strength. Collagen production, and thus, bone quality may be affected by MK-7 or MK-4 converted from MK-7. In this review, we comprehensively discuss the various properties of MK-7.
\end{abstract}

Keywords: vitamin K2; menaquinone-7; osteocalcin; bone metabolism; bone quality

\section{Introduction}

Vitamin $\mathrm{K}$ acts as a cofactor to $\gamma$-glutamyl carboxylase (GGCX), an enzyme that catalyzes glutamic acid residues of specific proteins to $\gamma$-carboxyglutamic acid (Gla) to form Gla-containing proteins. These proteins, also called vitamin K-dependent proteins (VKDPs) [1-11], are listed in Table 1. When intake of vitamin $\mathrm{K}$ is insufficient, VKDPs are not fully activated and fail to execute their specific functions.

Numerous blood coagulation factors, including coagulation factors II (prothrombin), VII, IX, and $\mathrm{X}$, and anti-coagulation factors, such as proteins $\mathrm{C}, \mathrm{S}$, and $\mathrm{Z}$, are well-known examples of VKDPs and are synthesized in the liver [1,2]. Thus, vitamin $\mathrm{K}$ is an indispensable nutrient for normal blood coagulation, and its deficiency rarely occurs in adults.

Functions of extrahepatic VKDPs have been extensively studied. Several VKDPs play important roles in maintaining bone metabolism and inhibiting ectopic calcification, leading to bone and cardiovascular health improvement [12]. For example, osteocalcin (OC) is synthesized by osteoblasts, the matrix Gla protein (MGP) is synthesized in vascular smooth muscle cells, cartilage, and bones, and the Gla-rich protein (GRP) is expressed in the cartilage and bones. Growth arrest-specific protein 6 (Gas6) expressed in the brain is involved in cell proliferation. On the other hand, the functions of certain VKDPs, that is, proline-rich Gla protein 1 (PRGP1), PRGP2, transglutaminase 3 (TGM3), and TGM4 are still not well-known. The VKDP GGCX is also expressed in almost all tissues. and there might be other VKDPs that are yet to be discovered.

In addition to activating various VKDPs, vitamin K acts as an antioxidant [13] and vitamin K2 or menaquinone-4 (MK-4) acts as a ligand of the steroid and xenobiotic receptor/pregnenolone $\mathrm{X}$ receptor (SXR/PXR) [14,15]. Thus, vitamin $\mathrm{K}$ is expected to have various health benefits [13], preventing or alleviating cardiovascular disease, bone fracture, diabetes mellitus, cancer, liver disease, chronic kidney disease, immune disorder, neurological disease, and obesity. 
Table 1. Vitamin K-dependent proteins.

\begin{tabular}{ccc}
\hline Protein & Function & Ref \\
\hline Factors II (Prothrombin), VII, IX, X & Procoagulants & {$[1,2]$} \\
Proteins C, S, Z & Anticoagulants & {$[1,2]$} \\
Osteocalcin & Regulator of mineral deposition & {$[3]$} \\
Matrix $\gamma$-carboxyglutamic acid protein & Inhibition of ectopic calcification & {$[4]$} \\
$\gamma$-carboxyglutamic acid-rich protein & Inhibition of ectopic calcification, & {$[5]$} \\
Periostin & anti-inflammatory & \\
Growth arrest-specific protein 6 & Inhibition of ectopic calcification, & {$[6]$} \\
Proline-rich $\gamma$-carboxy glutamyl proteins 1 & tissue regeneration & {$[7,8]$} \\
and 2 & Cell proliferation & {$[9,10]$} \\
$\gamma$-glutamyl carboxylase & Not well-known & {$[11]$} \\
\hline
\end{tabular}

Recently, vitamin K2 (MK-7) has been found to be highly effective in activating extrahepatic VKDPs at nutritional doses. In this study, we review the properties of MK-7.

\section{Sources of Vitamin K}

The two naturally occurring forms of vitamin K are vitamin K1 (phylloquinone) and vitamin K2 (menaquinone (MKs or MK-n)). Vitamin K1 occurs in various green vegetables and plant oils and is the primary dietary source of vitamin K [16]. Vitamin K1 is present in the chloroplast membrane of leafy green vegetables. Vitamin K2 has a variable side chain length of four to 15 isoprene units and is referred to as MK-n, where $n$ denotes the number of isoprenoid units. A small amount of MK-4 is found in animal products, such as eggs, meat, and liver. MK-4 in animal foods results from the conversion of vitamin $\mathrm{K} 1$ in plant feed or menadione (a synthetic analog of vitamin $\mathrm{K}$, containing only the 2-methyl-1,4-naphthoquinone ring structure), provided to animals as a feed additive $[17,18]$. The long chain MKs, such as MK-7-MK-9, are found in fermented foods. These MKs are also bacterial products found in fermented foods $[19,20]$. A Japanese traditional food, natto, is a unique soybean product fermented with a specific kind of Bacillus subtilis and contains MK-7 at a very high concentration $[19,20]$.

Bacteria present in the colon produce a substantial quantity of long chain MKs [21,22]. The extent to which intestinal bacteria-derived MKs contribute to the daily requirement of vitamin $\mathrm{K}$ has been a matter of debate $[23,24]$. However, it is thought that MKs derived from intestinal bacteria are difficult to be absorbed in the distal digestive tract, and some experiments have shown that MKs derived from intestinal flora alone are insufficient $[25,26]$.

Vitamin K1, MK-4, and MK-7 are currently used for fortification purposes by the food industry and as nutritional supplements (Figure 1). 


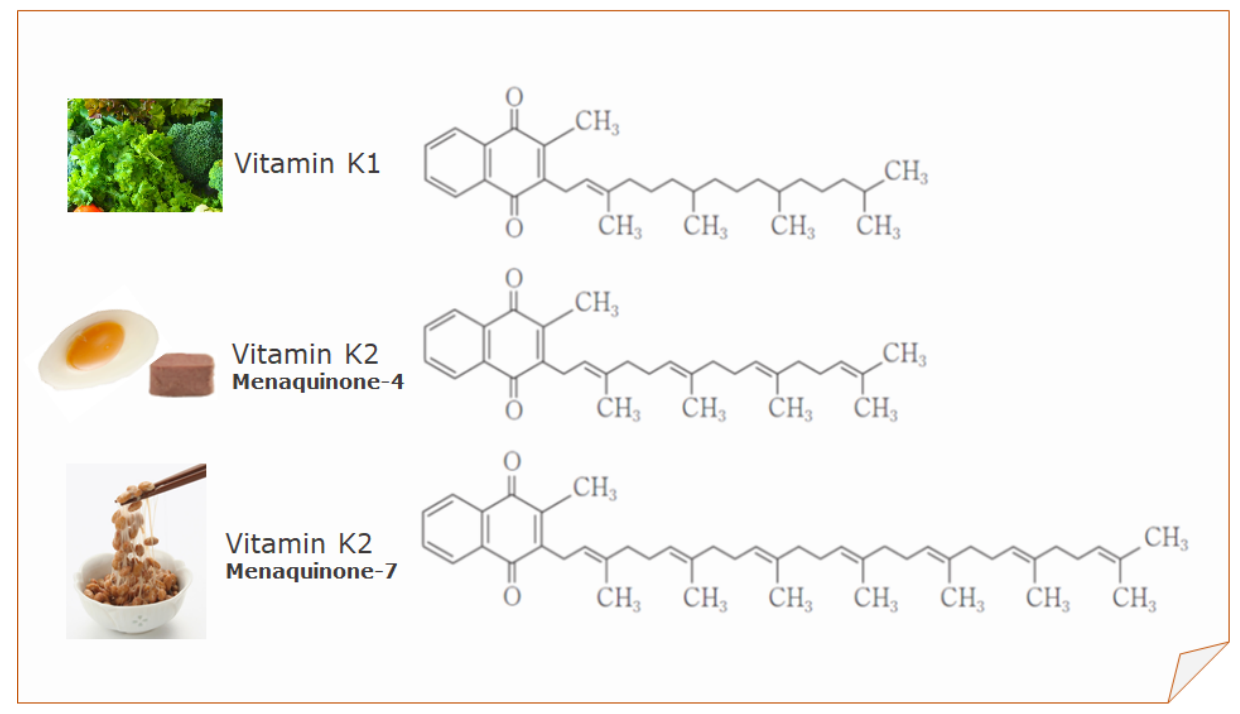

Figure 1. Structure of vitamin K1, menaquinone-4 (MK-4), and menaquinone-7 (MK-7).

\section{Daily Requirement of Vitamin K}

Currently, the recommended daily intake (RDI) or adequate intake (AI) of vitamin K is based on the maintenance of normal blood coagulation [27,28]. The National Academy of Medicine in the US has set the AI of vitamin $\mathrm{K} 1$ at $120 \mu \mathrm{g} /$ day for adult men and $90 \mu \mathrm{g} /$ day for adult women [29]. The World Health Organization and the Food and Agriculture Organization have set the recommended dosages for vitamin $\mathrm{K} 1$ at $65 \mu \mathrm{g} /$ day for men and $55 \mu \mathrm{g} /$ day for women, on the basis of $1 \mu \mathrm{g} / \mathrm{day} / \mathrm{kg}$ body weight [30]. The European Commission has set the recommended daily allowance (RDA) for vitamin $\mathrm{K}$ at $75 \mu \mathrm{g} /$ day [31]. Japan has set the AI of vitamin $\mathrm{K}$ at $75 \mu \mathrm{g} /$ day for adult men and $65 \mu \mathrm{g} /$ day for adult women by the Ministry of Health, Labor, and Welfare in 2010 [32], with both values being over $1 \mu \mathrm{g} /$ day/kg body weight.

However, studies have suggested that relatively higher vitamin $\mathrm{K}$ intake is required for bone and vascular health [33]. As vitamin $\mathrm{K}$ accumulates mostly in the liver and is used for coagulation, a greater quantity is thought to be required for extrahepatic tissues [34]. In a previous study, we demonstrated the AI for vitamin $\mathrm{K}$ for Japanese adult women set in 2010, that is, $65 \mu \mathrm{g} / \mathrm{day}$, is insufficient for the $\gamma$-carboxylation of osteocalcin (OC) [35]. Vitamin K intake from meals of all subjects was strictly controlled to an average of $72 \mu \mathrm{g} /$ day, mainly with vitamin K1 and small amounts of MK-4 throughout the study. We analyzed serum carboxylated OC (cOC) and undercarboxylated OC (ucOC), and determined the ratio of $\mathrm{COC} / \mathrm{ucOC}$, a sensitive marker of vitamin $\mathrm{K}$ status in bone. The ratio of cOC/ucOC significantly decreased after two weeks and decreased further by about $40 \%$ from baseline (Figure 2) [35]. Furthermore, cOC and ucOC concentrations continued to exhibit a tendency to decrease. Because daily intake of $72 \mu \mathrm{g} /$ day corresponds to $1.3 \mu \mathrm{g} /$ day/kg body weight, the results demonstrated that the current RDIs of vitamin K set by many countries are insufficient for the $\gamma$-carboxylation of OC. It should be noted that fabricated diets, such as enteral feeding products and multi-nutrient diets for hospitals prepared based on RDIs may result in vitamin K deficiency for bone metabolism, affecting bone health and increasing bone fracture risk. 


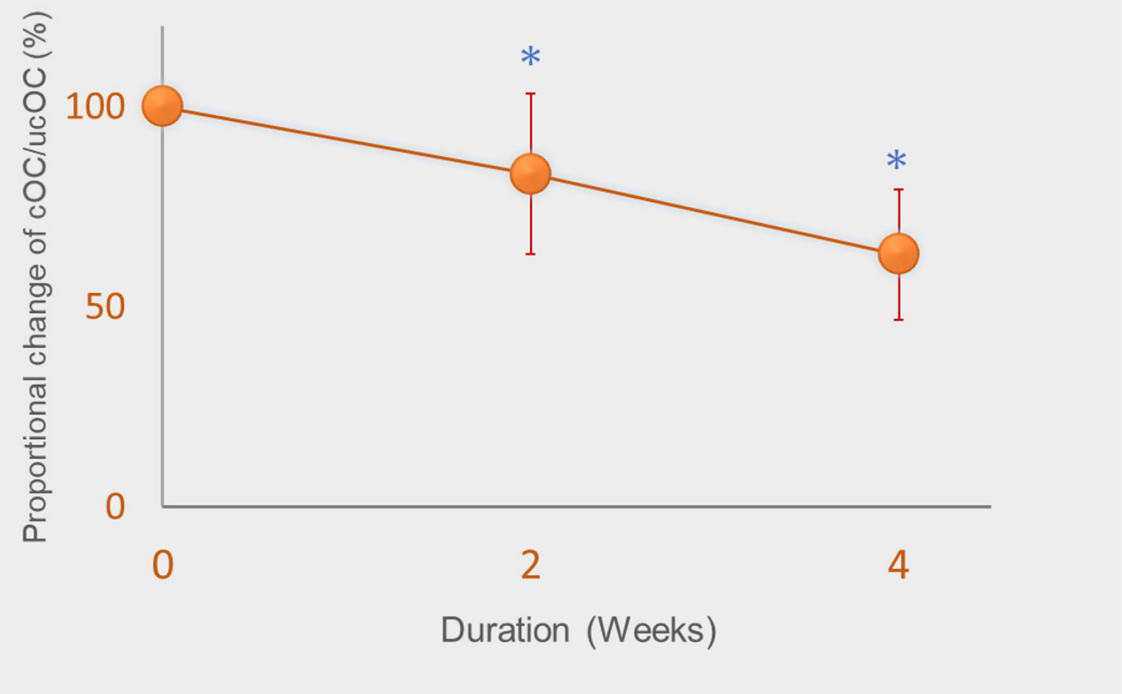

Figure 2. Change in the ratio of carboxylated osteocalcin (cOC) to undercarboxylated osteocalcin (ucOC) from baseline. Subjects were administered $72 \mu \mathrm{g}$ vitamin K/day (around adequate intake of vitamin K) for four weeks. Data are expressed as mean \pm standard deviation of $14-15$ subjects. * Significantly different from baseline, $p<0.001$. Adapted from [35].

In our study [35], an additional intake of $50 \mu \mathrm{g} /$ day of MK-7 protected the OC carboxylation rates or cOC/ucOC. In 2015, the Japanese daily AI for vitamin K for adults was increased almost two-fold to $150 \mu \mathrm{g} /$ day for both adult men and women. However, it is still unknown whether this level is sufficient for normal bone metabolism, as vitamin $\mathrm{K} 1$ from vegetables is poorly absorbed [20].

As vitamin K1, MK-4, and MK-7 have different intestinal absorption rates and blood half-lives in humans, their physiological activities are also considered to differ [36,37]. Thus, the RDIs for vitamin $\mathrm{K}$ homologs should be established based on their relative activities.

When higher doses over the RDA were used, no hypercoagulable state was observed [38]. The adverse effects of MK-7 has not been reported by prolonged supplementation of MK-7 for 3 years [39,40]. We found that an intake of $600 \mu \mathrm{g} / \mathrm{day}$ of MK-7 for one month did not affect biochemical parameters in serum and urine in healthy subjects. Safety of MK-7 has been reviewed by Marles et al. [28], and its use in food for fortification purposes has been approved in many countries.

\section{MK-7 and Bone Quality}

Natto, fermented soybean specifically produced by B. subtilis, is a traditional Japanese food high in MK-7 (200-400 $\mu \mathrm{g}$ per serving of 30-45 g). Due to its distinctive strong smell, stickiness, and texture, natto consumption varies markedly depending on the region. Regional studies have shown that natto consumption reduces incidences of hip fractures in women in Japan (Figure 3) [41,42]. Recently, a large prospective cohort study revealed that natto intake is inversely correlated with fracture risk [43]. In this study, frequency of intake of other soybean products had no association with fracture risk. The major difference between natto and other soybean products is that the former is prepared by fermentation using B. subtilis and contains a high amount of MK-7. Thus, the higher MK-7 levels due to natto consumption may have contributed to the relatively lower fracture risk [41-43]. Natto has been eaten for centuries in Japan, and no particularly problematic side effects have been reported. However, patients taking vitamin $\mathrm{K}$ antagonists (VKAs), such as warfarin, should refrain from taking natto, which may affect the stability of VKAs. 

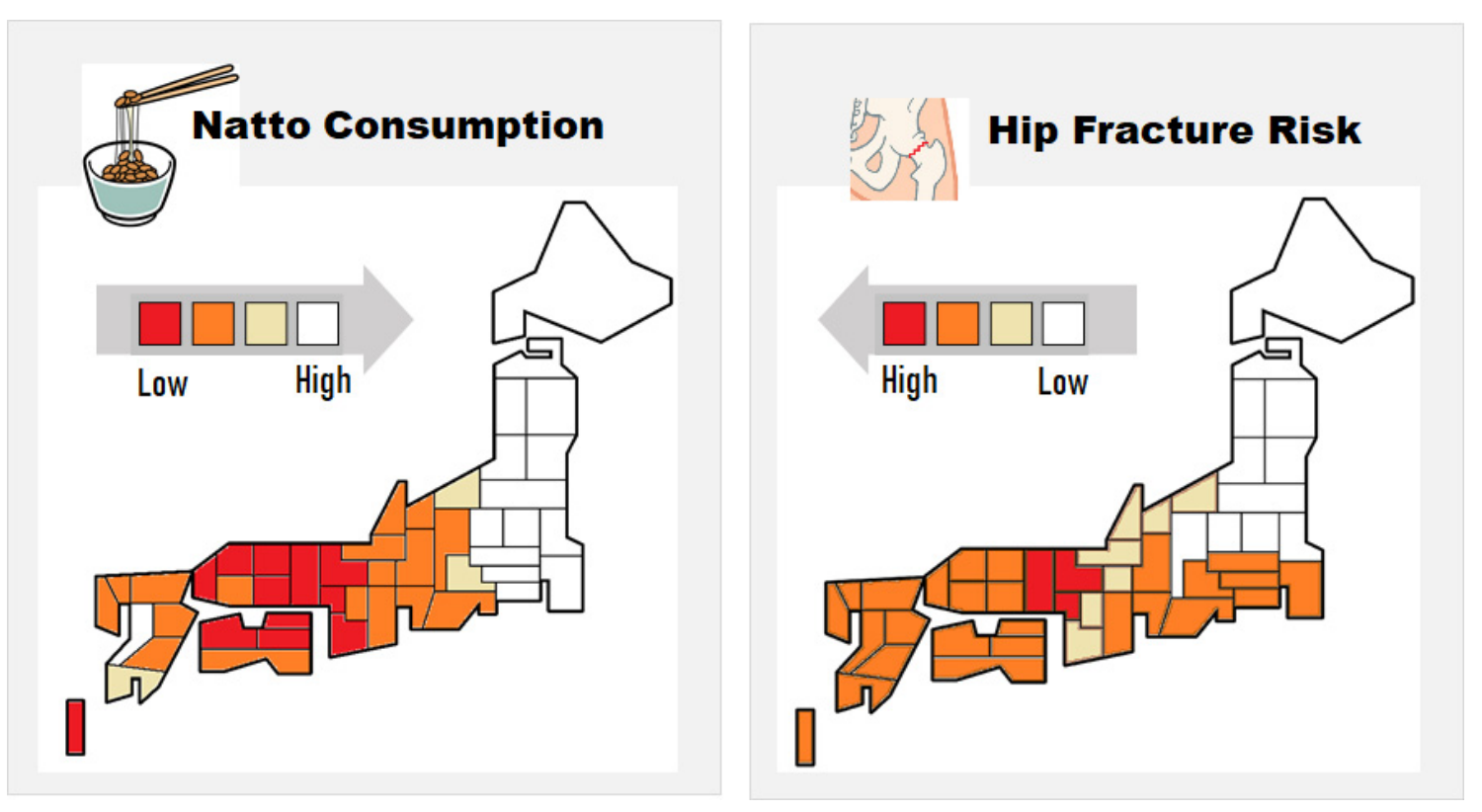

Figure 3. Correlation between the regional relative incidence of hip fractures and natto consumption in Japanese women. Adapted from [41].

The association of frequent natto intake with a reduced risk of osteoporotic fractures was shown to be independent of bone mineral density (BMD), suggesting that natto is beneficial for bone quality [43]. A study reported that administration of MK-7 for six weeks did not have any effects on bone strength and bone mineral density in ovariectomized rats [44]. However, another study showed that intake of MK-7 for five months prevented BMD loss to a certain extent, but significantly improved bone strength in rats (Figure 4) [45]. Therefore, the primary benefits of MK-7 are maintaining and improving bone quality, thus improving bone strength rather than increasing BMD. A clinical study demonstrated that postmenopausal women treated with a pharmacological dose of MK-4 (45 mg/day) for three years showed no effects on BMD, but bone quality indices of the femur increased [46]. In addition, MK-7 $(180 \mu \mathrm{g} /$ day $)$ was demonstrated to inhibit bone loss and helped maintain high bone strength in healthy postmenopausal women [39].
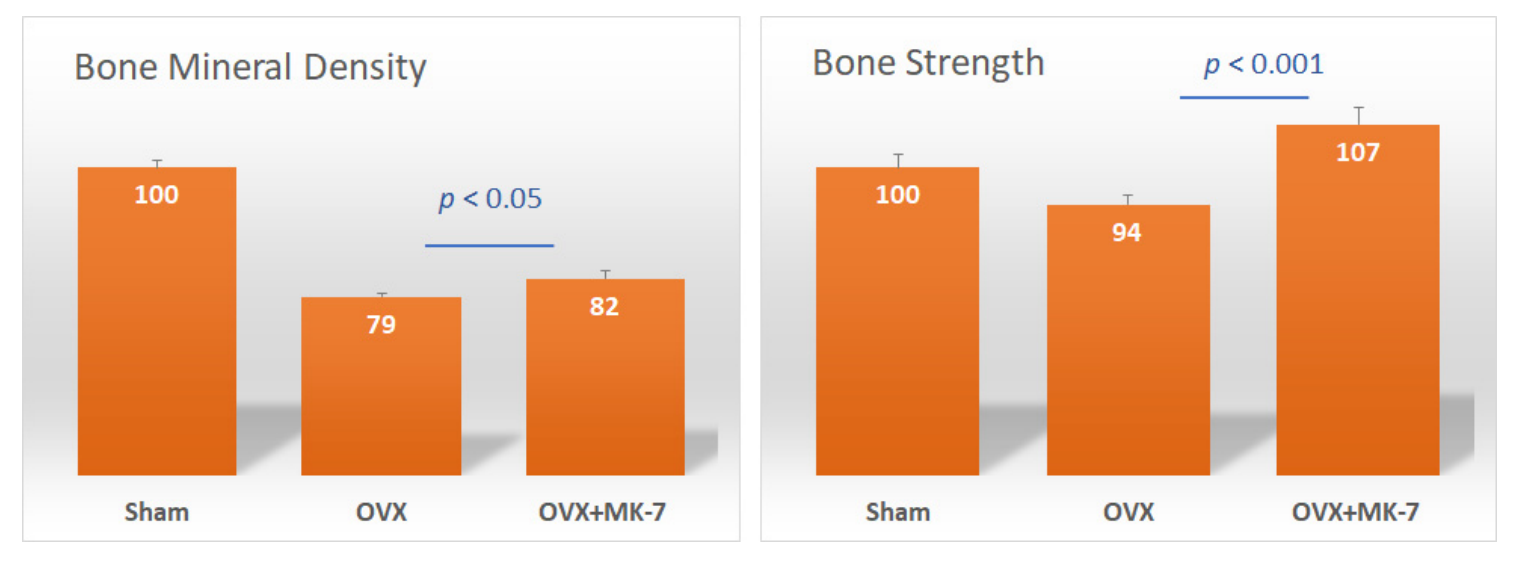

Figure 4. Effect of menaquinone-7 (MK-7) on bone mineral density (BMD) and bone strength of the femurs of ovariectomized rats. Sham: sham-operated group; OVX: ovariectomized rat control group; OVX + MK-7: ovariectomized rats that were fed MK-7. Data are expressed as relative values with the sham group taken as $100 \%$. Adapted from [45]. 
In addition to OC carboxylation, which modulates the deposition of calcium in bone, MK-4 increases collagen accumulation [47]. We also confirmed that MK-7 increased collagen production using osteoblasts [48]. Collagen is essential to bone flexibility and elasticity, and occupies more than half the volume of bones. It is responsible for matrix production, the material on which calcium and other minerals accumulate. Therefore, along with bone minerals, collagen accumulation is critical for high-quality bone formation.

Other than OC, many VKDPs, such as MGP, protein S [49], and periostin are produced in the bone matrix, suggesting a complex involvement of vitamin K and VKDPs in bones.

\section{Advantages of MK-7}

Osteocalcin has been used as a biomarker for bone metabolism. Vitamin K deficiency leads to an increase in serum ucOC, and a high serum ucOC level has been associated with hip fractures [50,51], and has been recognized as an independent risk factor for fractures. Since 2007, serum ucOC has been used as a diagnostic marker to evaluate vitamin $\mathrm{K}$ deficiency in bones in Japan. A smaller dose of MK-7 can $\gamma$-carboxylate OC compared to doses of K1 or MK-4. A supplemental intake of 250-1000 $\mu \mathrm{g} /$ day of vitamin $\mathrm{K} 1$ activates OC [52], which is higher than the current RDIs of vitamin $\mathrm{K}$ in most countries. A markedly higher dose of MK-4 (600-1500 $\mu \mathrm{g} /$ day) is required to activate OC [53,54], as it has been shown to have a very short half-life in humans [37] and it is poorly absorbed [55]. Nutritional doses of MK-4, such as the consecutive intake of $60 \mu \mathrm{g} /$ day or a single intake of $420 \mu \mathrm{g}$, have shown to be ineffective [55]. In contrast, MK-7 at doses around the current RDI (90-180 $\mu \mathrm{g} /$ day) promoted OC carboxylation $[35,38,56]$. A study demonstrated that MK-7 derived from natto has a very long half-life in the serum and induces more complete carboxylation of OC compared to vitamin $\mathrm{K} 1$ in humans [57].

As all vitamin K homologs are converted to MK-4 in tissues, MK-4 is considered to perform other specific functions other than $\gamma$-carboxylation of VKDPs [58,59]. However, in our previous study [60], the intake of a nutritional dose of MK-4 did not lead to an increase in MK-4 levels in the extrahepatic organs of rats, while that of MK-7 led to a significant increase in MK-4 in organs such as the femur, brain, and testis. This implies that to achieve MK-4-specific physiological effects, it might be better to intake MK-7 as a MK-4 precursor than MK-4 itself.

In addition to $\gamma$-carboxylation of VKDPs and the SXR-receptor ligand by conversion of MK-7 to MK-4, MK-7, the precursor of MK-4, directly activates bone formation by osteoblasts [61] and suppresses bone resorption [62]. It has also been shown that MK-7 stimulates osteoblastogenesis and suppresses osteoclastogenesis by inhibiting the activation of NF- $\mathrm{BB}$ [63].

\section{Conclusions}

Among vitamin $\mathrm{K}$ homologs, MK-7 has been shown to have the highest bioavailability and the most significant effect on OC carboxylation in humans. Vitamin K1 and MK-4 at their current RDIs are not sufficient for activation of OC. On the other hand, it is expected that MK-7 may promote bone health.

Author Contributions: Writing—review and editing, T.S.; Statistical analysis, N.I.; supervision, T.Y. All authors have read and agreed to the published version of the manuscript.

Funding: This research received no external funding.

Acknowledgments: We would like to thank Editage (www.editage.com) for English language editing.

Conflicts of Interest: The authors declare no conflict of interest.

\section{References}

1. Shearer, M.J. Vitamin K and vitamin K-dependent proteins. Br. J. Haematol. 1990, 75, 156-162. [CrossRef] [PubMed]

2. Furie, B.; Furie, B.C. The molecular basis of blood coagulation. Cell 1988, 53, 505-518. [CrossRef] 
3. Price, P.A. Role of vitamin-K-dependent proteins in bone metabolism. Annu. Rev. Nutr. 1988, 8, 565-583. [CrossRef] [PubMed]

4. Wei, F.F.; Trenson, S.; Verhamme, P.; Vermeer, C.; Staessen, J.A. Vitamin K-dependent matrix Gla protein as multifaceted protector of vascular and tissue integrity. Hypertension 2019, 73, 1160-1169. [CrossRef]

5. Cancela, M.L.; Conceico, N.; Laize, V. Gla-rich protein, a new player in tissue calcification? Adv. Nutr. 2012, 3, 174-181. [CrossRef]

6. Coutu, D.L.; Wu, J.H.; Monette, A.; Rivard, G.E.; Blostein, M.D.; Galipeau, J. Periostin, a member of a novel family of vitamin K-dependent proteins, is expressed by mesenchymal stromal cells. J. Biol. Chem. 2008, 283, 17991-18001. [CrossRef]

7. Ferland, G. Vitamin K and the nervous system: An overview of its actions. Adv. Nutr. 2012, 3, $204-212$. [CrossRef]

8. Laurance, S.; Lemarie, C.A.; Blostein, M.D. Growth arrest-specific gene 6 (gas6) and vascular hemostasis. Adv. Nutr. 2012, 3, 196-203. [CrossRef]

9. Kulman, J.D.; Harris, J.E.; Xie, L.; Davie, E.W. Proline-rich Gla protein 2 is a cell-surface vitamin K-dependent protein that binds to the transcriptional coactivator Yes-associated protein. Proc. Natl. Acad. Sci. USA 2007, 104, 8767-8772. [CrossRef]

10. Yazicioglu, M.N.; Monaldini, L.; Chu, K.; Khazi, F.R.; Murphy, S.L.; Huang, H.; Margaritis, P.; High, K.A. Cellular localization and characterization of cytosolic binding partners for Gla domain-containing proteins PRRG4 and PRRG2. J. Biol. Chem. 2013, 288, 25908-25914. [CrossRef]

11. Rishavy, M.A.; Berkner, K.L. Vitamin K oxygenation, glutamate carboxylation, and processivity: Defining the three critical facets of catalysis by the vitamin K-dependent carboxylase. Adv. Nutr. 2012, 3, 135-148. [CrossRef] [PubMed]

12. Willems, B.A.; Vermeer, C.; Reutelingsperger, C.P.; Schurgers, L.J. The realm of vitamin K dependent proteins: Shifting from coagulation toward calcification. Mol. Nutr. Food Res. 2014, 58, 1620-1635. [CrossRef] [PubMed]

13. Halder, M.; Petsophonsakul, P.; Akbulut, A.C.; Pavlic, A.; Bohan, F.; Anderson, E.; Maresz, K.; Kramann, R.; Schurgers, L. Vitamin K: Double bonds beyond coagulation insights into differences between vitamin K1 and K2 in health and disease. Int. J. Mol. Sci. 2019, 20, 896. [CrossRef] [PubMed]

14. Tabb, M.M.; Sun, A.; Zhou, C.; Grün, F.; Errandi, J.; Romero, K.; Pham, H.; Inoue, S.; Mallick, S.; Lin, M.; et al. Vitamin K2 regulation of bone homeostasis is mediated by the steroid and xenobiotic receptor SXR. J. Biol. Chem. 2003, 278, 43919-43927. [CrossRef] [PubMed]

15. Azuma, K.; Ouchi, Y.; Inoue, S. Vitamin K: Novel molecular mechanisms of action and its roles in osteoporosis. Geriatr. Gerontol. Int. 2014, 14, 1-7. [CrossRef] [PubMed]

16. Booth, S.L.; Suttie, J.W. Dietary intake and adequacy of vitamin K. J. Nutr. 1998, 128, 785-788. [CrossRef] [PubMed]

17. Suzuki, Y.; Okamoto, M. Production of hen's eggs rich in vitamin K. Nutr. Res. 1997, 17, 1607-1615. [CrossRef]

18. Terachi, T.; Inoue, Y.; Ashihara, N.; Kobayashi, M.; Ando, K.; Matsui, T. Plasma vitamin K concentration in horses supplemented with several vitamin K homologs. J. Anim. Sci. 2011, 89, 1056-1061. [CrossRef]

19. Sakano, T.; Notsumoto, S.; Nagaoka, T.; Morimoto, A.; Fujimoto, K.; Masuda, S.; Suzuki, Y.; Hirauchi, K. Measurement of $\mathrm{K}$ vitamins in food by high performance liquid chromatography with fluorometric detection. Vitamins 1988, 62, 393-398.

20. Schurgers, L.J.; Vermeer, C. Determination of phylloquinone and menaquinones in food. Effect of food matrix on circulating vitamin K concentrations. Haemostasis 2000, 30, 298-307. [CrossRef]

21. Collins, M.D.; Jones, D. Distribution of isoprenoid quinone structural types in bacteria and their taxonomic implications. Microbiol. Rev. 1981, 45, 316-354. [CrossRef] [PubMed]

22. Conly, J.M.; Stein, K. Quantitative and qualitative measurements of K vitamins in human intestinal contents. Am. J. Gastroenterol. 1992, 87, 311-316. [PubMed]

23. Uchida, K.; Nomura, Y.; Takase, H.; Harauchi, T.; Yoshizaki, T.; Nakao, H. Effects of vitamin K-deficient diets and fasting on blood coagulation factors in conventional and germfree rats. Jpn. J. Pharmacol. 1986, 40, 115-122. [CrossRef]

24. Will, B.H.; Suttie, J.W. Comparative metabolism of phylloquinone and menaquinone-9 in rat liver. J. Nutr. 1992, 122, 953-958. [CrossRef] [PubMed] 
25. Suttie, J.W.; Mummah-Schendel, L.L.; Shah, D.V.; Lyle, B.J.; Greger, J.L. Vitamin K deficiency from dietary vitamin K restriction in humans. Am. J. Clin. Nutr. 1988, 47, 475-480. [CrossRef] [PubMed]

26. Ferland, G.; Sadowski, J.A.; O’Brien, M.E. Dietary induced subclinical vitamin K deficiency in normal human subjects. J. Clin. Investig. 1993, 91, 1761-1768. [CrossRef]

27. Beulens, J.W.J.; Booth, S.L.; van den Heuvel, E.G.H.M.; Stoecklin, E.; Baka, A.; Vermeer, C. The role of menaquinones (vitamin K2) in human health. Br. J. Nutr. 2013, 110, 1357-1368. [CrossRef]

28. Marles, R.J.; Roe, A.L.; Oketch-Rabah, H.A. US Pharmacopeial Convention safety evaluation of menaquinone-7, a form of vitamin K. Nutr. Rev. 2017, 75, 553-578. [CrossRef]

29. National Research Council. Dietary Reference Intakes for Vitamin A, Vitamin K, Arsenic, Boron, Chromium, Copper, Iodine, Iron, Manganese, Molybdenum, Nickel, Silicon, Vanadium, and Zinc; National Academy Press: Washington, DC, USA, 2000; pp. 162-196. [CrossRef]

30. World Health Organization and Food and Agriculture Organization of the United Nations. Vitamin K. In Vitamin and Mineral Requirements in Human Nutrition, 2nd ed.; World Health Organization: Geneva, Switzerland, 2004; pp. 108-129. [CrossRef]

31. European Community. Commission Directive 2008/100/EC of 28 October 2008 Amending Council Directive 90/496/EEC on Nutrition Labelling for Food Stuffs as Regards Recommended Daily Allowances, Energy Conversion Factors and Definitions. Off. J. Eur. Union 2008, 285, 9.

32. Tanaka, K.; Terao, J.; Shidoji, Y.; Tamai, H.; Imai, E.; Okano, T. Dietary reference intake for Japanese 2010: Fat-Soluble Vitamins. J. Nutr. Sci. Vitaminol. 2013, 59, S57-S66. [CrossRef]

33. Cranenburg, E.C.; Schurgers, L.J.; Vermeer, C. Vitamin K: The coagulation vitamin that became omnipotent. Thromb. Haemost. 2007, 98, 120-125. [CrossRef] [PubMed]

34. McCann, J.C.; Ames, B.N. Vitamin K, an example of triage theory: Is micronutrient inadequacy linked to diseases of aging? Am. J. Clin. Nutr. 2009, 90, 889-907. [CrossRef] [PubMed]

35. Inaba, N.; Sato, T.; Yamashita, T. Low-dose daily intake of vitamin K2 (Menaquinone-7) improves osteocalcin $\gamma$-carboxylation: A double-blind, randomized controlled trial. J. Nutr. Sci. Vitaminol. 2015, 61, 471-480. [CrossRef] [PubMed]

36. Shearer, M.J.; Bach, A.; Kohlmeier, M. Chemistry, nutritional sources, tissue distribution and metabolism of vitamin K with special reference to bone health. J. Nutr. 1996, 126, 1181S-1186S. [CrossRef]

37. Schurgers, L.J.; Vermeer, C. Differential lipoprotein transport pathways of K-vitamins in healthy subjects. Biochim. Biophys. Acta 2002, 1570, 27-32. [CrossRef]

38. Theuwissen, E.; Cranenburg, E.C.; Knapen, M.H.; Magdeleyns, E.J.; Teunissen, K.J.; Schurgers, L.J.; Smit, E.; Vermeer, C. Low-dose menaquinone-7 supplementation improved extra-hepatic vitamin K status, but had no effect on thrombin generation in healthy subjects. Br. J. Nutr. 2012, 108, 1652-1657. [CrossRef]

39. Knapen, M.H.; Drummen, N.E.; Smit, E.; Vermeer, C.; Theuwissen, E. Three-year low-dose menaquinone-7 supplementation helps decrease bone loss in healthy postmenopausal women. Osteoporos Int. 2013, 24, 2499-2507. [CrossRef]

40. Knapen, M.H.J.; Braam, L.A.J.L.M.; Drummen, N.E.; Bekers, O.; Hoeks, A.P.G.; Vermeer, C. Menaquinone-7 supplementation improves arterial stiffness in healthy postmenopausal women. A double-blind randomised clinical trial. Thromb. Haemost. 2015, 113, 1135-1144. [CrossRef]

41. Kaneki, M.; Hodges, S.J.; Hosoi, T.; Fujiwara, S.; Lyons, A.; Crean, S.J.; Ishida, N.; Nakagawa, M.; Takechi, M.; Sano, Y.; et al. Japanese fermented soybean food as the major determinant of the large geographic difference in circulating concentrations of vitamin K2: Possible implications for hip-fracture risk. Nutrition 2001, 17, 315-321. [CrossRef]

42. Yaegashi, Y.; Onoda, T.; Tanno, K.; Kuribayashi, T.; Sakata, K.; Orimo, H. Association of hip fracture incidence and intake of calcium, magnesium, vitamin D., and vitamin K. Eur. J. Epidemiol. 2008, 23, 219-225. [CrossRef]

43. Kojima, A.; Ikehara, S.; Kamiya, K.; Kajita, E.; Sato, Y.; Kouda, K.; Tamaki, J.; Kagamimori, S.; Iki, M. Natto intake is inversely associated with osteoporotic fracture risk in postmenopausal Japanese women. J. Nutr. 2019, 150, 599-605. [CrossRef] [PubMed]

44. Fu, X.; Moreines, J.; Booth, S.L. Vitamin K supplementation does not prevent bone loss in ovariectomized Norway Rats. Nutr. Metab. 2012, 9, 12. [CrossRef] [PubMed]

45. Murasawa, H.; Araki, S.; Mitsui, M.; Shirota, S.; Ikeda, R. Studies on high-vitamin K containing natto and its effect on osteoporosis. In Shokuhinsozai no Kinousei Souzou Seigyo Gijutsu, 1st ed.; The Japanese Research and Development Association for New Functional Foods, Koseisha Koseikaku: Tokyo, Japan, 1999; pp. 131-146. 
46. Knapen, M.H.; Schurgers, L.J.; Vermeer, C. Vitamin K2 supplementation improves hip bone geometry and bone strength indices in postmenopausal women. Osteoporosis Int. 2007, 18, 963-972. [CrossRef] [PubMed]

47. Ichikawa, T.; Horie-Inoue, K.; Ikeda, K.; Blumberg, B.; Inoue, S. Steroid and xenobiotic receptor SXR mediates vitamin K2-activated transcription of extracellular matrix-related genes and collagen accumulation in osteoblastic cells. J. Biol. Chem. 2006, 281, 16927-16934. [CrossRef]

48. Sato, T. Vitamin K2 and Bone Quality. Vitam. Trace Elem. 2012, S6. [CrossRef]

49. Maillard, C.; Berruyer, M.; Serre, C.M.; Dechavanne, M.; Delmas, P.D. Protein-S, a vitamin K-dependent protein, is a bone matrix component synthesized and secreted by osteoblasts. Endocrinology 1992, 130, 1599-1604. [CrossRef]

50. Seibel, M.J.; Robins, S.P.; Bilezikian, J.P. Serum undercarboxylated osteocalcin and the risk of hip fracture. J. Clin. Endorcinol. Metab. 1997, 82, 717-718. [CrossRef]

51. Vergnaud, P.; Garnero, P.; Meunier, P.J.; Bréart, G.; Kamihagi, K.; Delmas, P.D. Undercarboxylated osteocalcin measured with a specific immunoassay predicts hip fracture in elderly women: The EPIDOS study. J. Clin. Endocrinol. Metab. 1997, 82, 719-724. [CrossRef]

52. Binkley, N.C.; Krueger, D.C.; Kawahara, T.N.; Engelke, J.A.; Chappell, R.J.; Suttie, J.W. A high phylloquinone intake is required to achieve maximal osteocalcin gamma-carboxylation. Am. J. Clin. Nutr. 2002, 76, 1055-1060. [CrossRef]

53. Takeuchi, A.; Masuda, Y.; Kimura, M.; Marushima, R.; Matsuoka, R.; Hasegawa, M.; Takahara, M.; Onuki, M. Minimal effective dose of vitamin K2 (menaquinone-4) on serum osteocalcin concentration in Japanese subjects and safety evaluation of vitamin K2 supplemented in calcium tablet. J. Jpn. Soc. Clin. Nutr. 2005, 26, 254-260.

54. Nakamura, E.; Aoki, M.; Watanabe, F.; Kamimura, A. Low-dose menaquinone-4 improves $\gamma$-carboxylation of osteocalcin in young males: A non-placebo-controlled dose-response study. Nutr. J. 2014, 13, 85. [CrossRef] [PubMed]

55. Sato, T.; Schurgers, L.J.; Uenishi, K. Comparison of menaquinone-4 and menaquinone-7 bioavailability in Japanese. Nutr. J. 2012, 11, 93. [CrossRef]

56. Brugè, F.; Bacchetti, T.; Principi, F.; Littarru, G.P.; Tiano, L. Olive oil supplemented with menaquinone-7 significantly affects osteocalcin carboxylation. Br. J. Nutr. 2011, 106, 1058-1062. [CrossRef] [PubMed]

57. Schurgers, L.J.; Teunissen, K.J.; Hamulyak, K.; Knapen, M.H.; Vik, H.; Vermeer, C. Vitamin K-containing dietary supplements: Comparison of synthetic vitamin K1 and natto-derived menaquinone-7. Blood 2007, 109, 3279-3283. [CrossRef] [PubMed]

58. Komai, M.; Shirakawa, H. Vitamin K metabolism. Menaquinone-4 (MK-4) formation from ingested VK analogues and its potent relation to bone function. Clin. Calcium. 2007, 17, 1663-1672. [PubMed]

59. Nakagawa, K.; Hirota, Y.; Sawada, N.; Yuge, N.; Watanabe, M.; Uchino, Y.; Okuda, N.; Shimomura, Y.; Suhara, Y.; Okano, T. Identification of UBIAD1 as a novel human menaquinone-4 biosynthetic enzyme. Nature 2010, 468, 117-121. [CrossRef]

60. Sato, T.; Kawahara, R.; Kamo, S.; Saito, S. Comparison of menaquinone-4 and menaquinone-7 in rats. Vitamins 2007, 81, 377-381.

61. Yamaguchi, M.; Sugimoto, E.; Hachiya, S. Stimulatory effect of menaquinone-7 (vitamin K2) on osteoblastic bone formation in vitro. Mol. Cell. Biochem. 2001, 223, 131-137. [CrossRef]

62. Yamaguchi, M.; Ma, Z.J. Inhibitory effect of menaquinone-7 (vitamin K2) on osteoclast-like cell formation and osteoclastic bone resorption in rat bone tissues in vitro. Mol. Cell. Biochem. 2001, 228, 39-47. [CrossRef]

63. Yamaguchi, M.; Weitzmann, M.N. Vitamin K2 stimulates osteoblastogenesis and suppresses osteoclastogenesis by suppressing NF-kB activation. Int. J. Mol. Med. 2011, 27, 3-14. [CrossRef]

(C) 2020 by the authors. Licensee MDPI, Basel, Switzerland. This article is an open access article distributed under the terms and conditions of the Creative Commons Attribution (CC BY) license (http://creativecommons.org/licenses/by/4.0/). 